\title{
Protein-degradation products and bacterial enzyme activities in faeces of breast-fed and formula-fed infants
}

\author{
Patricia M. Heavey ${ }^{1 *}$, Shirley-Anne H. Savage ${ }^{2}$, Alison Parrett ${ }^{2}$, \\ Cinzia Cecchini ${ }^{3}$, Christine A. Edwards ${ }^{2}$ and Ian R. Rowland ${ }^{1}$ \\ ${ }^{1}$ Northern Ireland Centre for Diet and Health, Biomedical Sciences, University of Ulster, \\ Coleraine BT52 1SA, Northern Ireland, UK \\ ${ }^{2}$ The Department of Human Nutrition, University of Glasgow, Yorkhill Hospitals, Glasgow G3 8SJ, Scotland, UK \\ ${ }^{3}$ Laboratory of Microbiology, Camerino University, 62032 Camerino (MC), Italy
}

(Received 11 January 2002 - Revised 5 November 2002 - Accepted 18 November 2002)

\begin{abstract}
The aim of the present study was to determine the effects of age and diet (breast milk, formula milk and weaning diet) on metabolic activities in faecal samples from infants aged 1 week to 1 year, and to compare these findings with activities found in samples from adults. Such activities can provide valuable information on functional changes in the microbiota that may have significance for the health of the host. Fresh faecal samples were collected from forty-four breast-fed infants (twenty-four males, twenty females) and thirteen formula-fed infants (three males, ten females) throughout the first year of life. The samples were analysed for protein-breakdown products, including the faecal concentrations of $\mathrm{NH}_{3}$, phenol and $p$-cresol, and faecal bacterial enzyme activities. There was wide individual variation in all variables measured; however, the values in infants were substantially lower then those found in adults. In pre-weaned infants, faecal $\mathrm{NH}_{3}$ concentration and $\beta$-glucuronidase activity were the only endpoints that were significantly different in breast-fed and formula-fed infants $(P<0.001$ and $P<0.05$ respectively). This was not apparent after weaning. There was a significant difference between the breast-fed and formula-fed weaned groups and their pre-weaned counterparts only for $\mathrm{NH}_{3}(P<0.05)$. $\beta$-Glucuronidase activity and phenol concentration were significantly $(P<0 \cdot 01)$ greater in weaned breast-fed infants compared with pre-weaned breast-fed infants. No differences were observed between pre-weaned and weaned formula-fed infants for any of the variables except for $\mathrm{NH}_{3}$ concentration. It can be concluded from the present study that there are significant differences in two faecal characteristics between breast- and formula-fed infants and that changes occur as the infants grow older and are weaned onto solid foods.
\end{abstract}

Infants: Faecal samples: Bacterial protein-degradation products: Enzyme activity

At birth, the gastrointestinal tract is sterile (Escherich, 1885). In an infant's first postnatal week, the gastrointestinal tract is exposed to a wide variety of organisms, reflecting a range of external influences such as the mother's vaginal, faecal and skin floras, and also the extent of bacterial contamination from the perinatal environment (Gareau et al. 1959; Bettelheim \& Lennox-King, 1976; Sarkany \& Gaylarde, 1986). The bacterial contamination of the newborn infant is influenced by mode of delivery and contact with the mother and external environment, which leads to individual patterns of colonisation. Although the infant is exposed to diverse bacteria, not all are able to establish themselves within the neonatal intestine. Bacteria capable of aerobic growth, such as enterobacteria, streptococci and staphylococci, are the first to proliferate in the infant (Mata \& Urrutia, 1971; Balmer \& Wharton, 1989), as a consequence of a positive oxidation-reduction potential in the gut. As these facultative and aerobic bacteria increase in numbers, they consume $\mathrm{O}_{2}$, lowering the redox potential and thus allowing anaerobic bacteria to proliferate (Stark \& Lee, 1982). Anaerobic bacteria most commonly found in the newborn include bifidobacteria, clostridia and bacteroides (Stark \& Lee, 1982).

Once a feeding regimen has commenced, a pattern begins to emerge in the microbiota of the gut and here differences have been reported between breast- and formula-fed infants (Yoshioka et al. 1983; Benno et al. 1984; Heavey \& Rowland, 1999). Further, it would 
appear that breast-fed infants have a simple microbiota, consisting of bifidobacteria, enterococci and enterobacteria, with formula-fed infants having more clostridia and bacteroides than their breast-fed counterparts. Infants usually acquire a microbiota similar to that of adults within 2 years (Stark \& Lee, 1982).

Most studies have focused on the bacteriology of the developing infant; however, there are some reports that these bacterial changes are also associated with marked changes in metabolic activity. For example, several investigators have studied microbiota-associated changes, such as mucin and bilirubin degradation and cholesterol metabolism, in faeces of infants up to 2 years old (Norin et al. 1985; Midtvedt \& Midtvedt, 1992), and there have been comparisons of carbohydrate metabolism in breast- and formula-fed infants (Lifschifz et al. 1990; Midtvedt \& Midtvedt, 1993; Parrett \& Edwards, 1997). Less well studied have been potentially detrimental metabolic processes in the intestine, in particular, the metabolites produced by bacterial fermentation of proteins and amino acids and also bacterial enzymes that may yield toxic products (Rowland, 1992, 1995). In infants, it has long been established that breast milk is the ideal food for the developing infant and of particular interest is the human-milk protein fraction. The protein concentration of human milk is the lowest of all mammalian species and results in almost complete utilisation of the protein component by the infant. The main products of bacterial protein degradation, which include $\mathrm{NH}_{3}$, phenol and $p$-cresol, can exert toxic effects, both systemically in the body, and locally on the gut mucosa (Bakke, 1969; Visek, 1978; MacFarlane et al. 1986).

It is well documented that the products of bacterial enzymes, such as $\beta$-glucuronidase and $\beta$-glucosidase, can exert damaging effects on the host (Goldin, 1986; Rowland, 1992). $\beta$-Glucuronidase acts on ingested toxicants that have been conjugated to glucuronic acid in the liver and secreted into the gut via the biliary tract. Hydrolysis of the conjugates releases potentially toxic aglycones in the colon. Similarly, $\beta$-glucosidase can hydrolyse glucoside conjugates found in plants, releasing biologically active phytochemicals (Gangolli \& Rowland, 1999).

Analysis of protein-breakdown products and assays of metabolic processes in the faeces can provide valuable information on functional changes in the microbiota that may have significance for the health of the host (Rowland, 1992, 1995). In the present study, we have investigated such functional changes in developing infants fed breast or formula milk.

\section{Materials and methods}

\section{Subjects}

Fifty-seven full-term newborn infants were recruited from the Glasgow (Scotland) area. Mothers were approached within $2 \mathrm{~d}$ of giving birth, and those who were exclusively breast-feeding or exclusively formula-feeding (Aptamil; Milupa Research, Friedrichsdorf, Germany) were invited to participate in the study. None of these infants or their mothers had received any antibiotics at the time of recruitment or at any time before giving samples. Fresh faecal samples were collected from forty-four breast-fed infants (twenty-four males, twenty females) and thirteen formula-fed infants (three males, ten females) at several time points during the first year. These were usually 1 week, 4 weeks, 2 months, early weaning (4 weeks after first non-milk foods), 7 months, 9 months and 1 year. The mothers chose to wean at ages that were not influenced by the authors. At the time of recruitment, there was a breast-feeding initiative underway to encourage breast-feeding. This resulted in fewer formula-fed infants participating in the study.

\section{Ethical approval}

This study was approved by the Ethics Committee of Yorkhill NHS Trust, Glasgow. The mothers of all infants gave their informed written consent.

\section{Faecal samples}

Faecal samples were collected from the infants at their homes and were processed within $2 \mathrm{~h}$ of defecation. When the mother had detected a soiled nappy, she immediately telephoned the department and the nappy was collected by car. To facilitate this process, mothers and infants were recruited from a zone of $30 \mathrm{~min}$ travel from the laboratory. Samples were weighed and a faecal suspension $(100 \mathrm{~g} / \mathrm{l})$ was prepared with distilled water. The samples were kept frozen $\left(-20^{\circ} \mathrm{C}\right)$ until subsequent analysis. The $\mathrm{pH}$ of the samples was measured when the samples were thawed. Due to their small size, not all variables were measured for each sample. For comparison purposes, faecal samples from nine adults (aged 21-28 years) were collected and subjected to similar treatment.

\section{Faecal ammonia concentration}

Concentration of faecal $\mathrm{NH}_{3}$ was determined by spectrophotometry as described by Solorzano (1969). Briefly, the faecal suspensions were diluted and centrifuged at $5000 \mathrm{~g}$ for $5 \mathrm{~min}$. A sample of the supernatant fraction $(0.5 \mathrm{ml})$ was added to $0.5 \mathrm{ml}$ phenol-nitroprusside solution, $0.5 \mathrm{ml}$ alkaline hypochlorite solution (both from SigmaAldrich Co. Ltd, Poole, Dorset, UK) and $3.5 \mathrm{ml}$ water and left at room temperature for $40 \mathrm{~min}$. Absorbance was measured at $570 \mathrm{~nm}$ and related to $\mathrm{NH}_{3}$ concentration by reference to a standard curve.

\section{Faecal production of ammonia}

The rate of production of $\mathrm{NH}_{3}$ from endogenous $\mathrm{N}$ sources in the faeces was determined according to Wise et al. (1982). The faecal samples were diluted with $0 \cdot 1$ M-potassium phosphate buffer (at a $\mathrm{pH}$ within $0.2 \mathrm{pH}$ units of that of the sample) to a final concentration of $200 \mathrm{~g} / \mathrm{l}$. The suspensions were incubated at $37^{\circ} \mathrm{C}$ for $15 \mathrm{~min}$ and samples $(0.7 \mathrm{ml})$ removed at $3 \mathrm{~min}$ intervals and kept on ice. The samples were centrifuged at $5000 \mathrm{~g}$ for $5 \mathrm{~min}$ and $\mathrm{NH}_{3}$ determined as described earlier. 


\section{Measurement of phenol and p-cresol}

The concentration of phenol and $p$-cresol in faeces was determined by GC. A sample of faecal supernatant fraction (1 ml) was heated with $0.1 \mathrm{ml}$ internal standard solution (20 mM-p-methoxyphenol), $1.0 \mathrm{ml}$ methanol and $0.2 \mathrm{ml} \mathrm{H}_{2} \mathrm{SO}_{4}$ $(500 \mathrm{ml} / \mathrm{l})$ in a water-bath at $70^{\circ} \mathrm{C}$ for $50 \mathrm{~min}$. Distilled water $(0.2 \mathrm{ml})$ and chloroform $(0.8 \mathrm{ml})$ were added after the reaction mixture had cooled. The chloroform layer containing derivatised phenolic compounds was extracted, and $5 \mu \mathrm{l}$ were injected onto a $25 \mathrm{~m} \times 0.25 \mathrm{~mm} \mathrm{CP}-$ Sil $5 \mathrm{CB}$ column in a Perkin Elmer auto system GC (model 970; Perkin Elmer, Norwalk, CT, USA). The carrier gas (He), $\mathrm{H}_{2}$ and air were set at flow rates of $25 \mathrm{~cm}^{3} / \mathrm{s}, 45$ and $450 \mathrm{ml} / \mathrm{min}$ respectively. The injection port temperature was $250^{\circ} \mathrm{C}$ and the detector temperature was $300^{\circ} \mathrm{C}$. Identification of peaks was made by coincidence of retention times with the standards. Quantitative assessment was made by comparison of peak areas of test samples with those of authentic phenol and $p$-cresol standards.

\section{Determination of $\beta$-glucosidase and $\beta$-glucuronidase}

The $\mathrm{pH}$ of the diluted faecal samples was measured and assays for both enzymes were conducted at a buffered $\mathrm{pH}$ closest (within $0.2 \mathrm{pH}$ units) to that of the samples. The suspensions were incubated at $37^{\circ} \mathrm{C}$ with $3 \mathrm{~mm}-p$-nitrophenyl- $\beta$-D-glucopyranoside or $3 \mathrm{~mm}-p$-nitrophenyl- $\beta$-D-glucuronide (Sigma-Aldrich Co. Ltd) for assessment of $\beta$-glucosidase and $\beta$-glucuronidase respectively. Release of $p$-nitrophenol was measured colorimetrically over time and used as the measure of enzyme activity (Wise et al. 1982).

\section{Statistical analyses}

Data for $\mathrm{NH}_{3}$ concentration and production and $\beta$-glucuronidase and $\beta$-glucosidase activities were transformed $\left(\log _{10}\right)$ and compared using one-way ANOVA, and comparisons between means were compared by the least significant difference criterion. For statistical analyses, we have included only those infants who provided faecal samples both before and after weaning. In the case of those infants who provided more then one sample within the pre- or post-weaning periods, an average of these samples was taken and treated as a single value.

\section{Results \\ Age of weaning}

All infants were weaned between 12 and 20 weeks inclusive.

\section{Faecal pH}

Most infant faecal samples were acidic, with a mean $\mathrm{pH}$ of 6.7 (SD 0.9) (range 4.3-8.6). Faecal pH increased gradually as the infants got older $(6 \cdot 5$ at $<4$ weeks old to $7 \cdot 2$ in infants $>36$ weeks old) and there was a significant difference between all infants $<4$ weeks old and those $>36$ weeks old $(P=0 \cdot 002)$.

\section{Ammonia concentration}

There was wide individual variation in faecal $\mathrm{NH}_{3}$ concentrations, which ranged from 0.00 to $41.39 \mu \mathrm{mol} / \mathrm{g}$ in infants aged from 1 week to 1 year (Tables 1 and 2). These values were substantially lower than those found in adults, although there was overlap between some older infants and adults (Table 1). In both breast- and formula-fed infants the concentration of $\mathrm{NH}_{3}$ generally tended to increase with age (Table 2). The results shown in Table 2 demonstrate that many of the variables measured increased over time as a result of either age or diet or a combination of the two. However, statistical analysis was not carried out, since not all infants provided samples for all time points. When the infants were grouped according to weaning status, there was a significant difference between breastand formula-fed infants prior to weaning $(P<0.001$, Table 3). However, this was not evident after weaning. There was also a significant difference between preweaned and weaned breast-fed infants $(P<0 \cdot 001) . \mathrm{NH}_{3}$

Table 1. Comparison of faecal bacterial metabolites in infants (1 week-12 months old) and adults (Mean values, standard deviations and ranges)

\begin{tabular}{|c|c|c|c|c|c|c|c|c|}
\hline & \multicolumn{4}{|c|}{ Infants } & \multicolumn{4}{|c|}{ Adults } \\
\hline & Mean & SD & Range & $n$ & Mean & SD & Range & $n$ \\
\hline Ammonia concentration $(\mu \mathrm{mol} / \mathrm{g}) \dagger$ & $7 \cdot 68$ & $7 \cdot 15$ & $0.00-41.39$ & 175 & 37.86 & $32 \cdot 21$ & $8 \cdot 81-109 \cdot 79$ & 9 \\
\hline Ammonia production $(\mu \mathrm{mol} / \mathrm{g}$ per $\mathrm{h}) \ddagger$ & $5 \cdot 86$ & $6 \cdot 53$ & $0.00-33.99$ & 175 & 41.35 & 28.93 & $12 \cdot 93-70 \cdot 33$ & 4 \\
\hline Phenol concentration $(\mathrm{mmol} / \mathrm{kg}) \S$ & 0.58 & 0.84 & $0.00-6.30$ & 112 & 2.79 & 0.38 & $2.53-3.06$ & 2 \\
\hline$p$-Cresol concentration $(\mathrm{mmol} / \mathrm{kg}) \|$ & 0.14 & 0.14 & $0.00-0.53$ & 112 & 0.28 & 0.06 & $0.26-0.31$ & 2 \\
\hline $\begin{array}{l}\beta \text {-Glucuronidase activity } \\
\quad(\mu \mathrm{mol} \text { product formed } / \mathrm{h} \text { per g faeces })\end{array}$ & $11 \cdot 87$ & 11.09 & $0.00-65 \cdot 22$ & 133 & $33 \cdot 32$ & $21 \cdot 44$ & $17 \cdot 94-63 \cdot 74$ & 4 \\
\hline $\begin{array}{l}\beta \text {-Glucosidase activity } \\
\quad(\mu \mathrm{mol} \text { product formed } / \mathrm{h} \text { per g faeces })^{\star \star}\end{array}$ & $16 \cdot 55$ & $15 \cdot 38$ & $0.00-73.47$ & 133 & $35 \cdot 61$ & $7 \cdot 12$ & $28 \cdot 33-45 \cdot 64$ & 4 \\
\hline
\end{tabular}

${ }^{*}$ For details of subjects and procedures, see p. 510.

† Mean age: infants 22 weeks, adults 24.9 years.

$\ddagger$ Mean age: infants 22 weeks, adults 24.7 years.

$\S$ Mean age: infants 18 weeks, adults 24.5 years.

|| Mean age: infants 18 weeks, adults 24.5 years.

9 Mean age: infants 14 weeks, adults 24.7 years.

${ }^{\star \star}$ Mean age: infants 14 weeks, adults 24.7 years. 
concentration was also significantly increased in weaned formula-fed infants compared with their pre-weaned counterparts $(P=0 \cdot 039)$.

\section{Ammonia production}

There was wide individual variation in faecal $\mathrm{NH}_{3}$ production, which ranged from $0.00-33.99 \mu \mathrm{mol} / \mathrm{g}$ per $\mathrm{h}$ in infants aged from 1 week to 1 year (Tables 1 and 2). Overall, these values were substantially less than those found in adults (Table 1). When infants were grouped according to weaning status, there were no significant differences in production rates between any of the groups (Table 3).

\section{Phenol and p-cresol concentration}

Phenol and $p$-cresol were not detected in any faecal samples from infants up to the age of 3 weeks, and levels remained low prior to weaning (Table 4). Levels of phenol and $p$-cresol in all infants were lower than those found in adults (Table 1). When the infants were grouped according to weaning status, there was no significant difference between pre-weaned breast- or formula-fed infants for either phenol or $p$-cresol (Table 3). However, phenol concentration was significantly higher in weaned $v$. non-weaned breast-fed infants $(P<0.003$, Table 3$)$.

Again, there was no difference between pre-weaned breast- and formula-fed infants for $p$-cresol concentration (Table 3). Similarly, no differences were observed between either breast- or formula-fed infants when comparing preweaned and weaned infants (Table 3).

\section{Bacterial enzyme activities}

The mean activities of $\beta$-glucuronidase and $\beta$-glucosidase were less in the infants compared with adults (Table 1), although some individual infants had higher activity for the enzymes than that found in the adults. Bacterial enzyme activities appeared to increase as the infants became older and were introduced to a more varied diet. When the infants were grouped according to weaning status, $\beta$-glucuronidase activity was statistically higher in the pre-weaned formula-fed infants compared with the pre-weaned breast-fed infants $(P=0.034$, Table 3). After weaning there was an increase in enzyme activity in both breast- and formula-fed infants compared with their preweaned counterparts, although this was not significant.

Table 3 also shows $\beta$-glucosidase activity, which was slightly lower in the pre-weaned breast-fed infants compared with the pre-weaned formula-fed infants. There was an increase in $\beta$-glucosidase activity in both breast-fed and formula-fed infants post-weaning compared with their preweaned counterparts, although again this was not significant.

\section{Discussion}

The present study provides observational results with regard to several metabolic activities in breast- and formula-fed infants throughout the first year of life. The results indicate that the pronounced changes reported in microbial composition of the gut flora in early life (Stark 
Table 3. Faecal ammonia concentration and production, phenol, $p$-cresol concentrations and enzyme activities in breast-fed and formula-fed infants $\ddagger$

(Mean values and standard deviations)

\begin{tabular}{|c|c|c|c|c|c|c|c|c|c|c|c|c|}
\hline \multirow{3}{*}{ Diet... } & \multicolumn{6}{|c|}{ Breast-fed } & \multicolumn{6}{|c|}{ Formula-fed } \\
\hline & \multicolumn{3}{|c|}{ Pre-weaned } & \multicolumn{3}{|c|}{ Weaned } & \multicolumn{3}{|c|}{ Pre-weaned } & \multicolumn{3}{|c|}{ Weaned } \\
\hline & Mean & SD & $n$ & Mean & SD & $n$ & Mean & SD & $n$ & Mean & SD & $n$ \\
\hline Ammonia concentration $(\mu \mathrm{mol} / \mathrm{g}) \S$ & $3 \cdot 30$ & $2 \cdot 31$ & 21 & $9 \cdot 67^{\star \star \star}$ & $6 \cdot 20$ & 21 & $7 \cdot 79^{\star \star \star}$ & 4.90 & 11 & $12 \cdot 70 \dagger$ & 5.85 & 11 \\
\hline Ammonia production $(\mu \mathrm{mol} / \mathrm{h}$ per $\mathrm{g}) \S$ & 4.93 & 6.47 & 21 & $5 \cdot 30$ & 3.37 & 21 & 6.66 & $7 \cdot 76$ & 11 & 7.02 & $7 \cdot 15$ & 11 \\
\hline$\beta$-Glucuronidase activity $(\mu \mathrm{mol} / \mathrm{h}$ per $\mathrm{g}) \|$ & $7 \cdot 22$ & $5 \cdot 62$ & 16 & 11.97 & 11.33 & 16 & $14 \cdot 38^{*}$ & $9 \cdot 18$ & 9 & $17 \cdot 69$ & 12.55 & 9 \\
\hline$\beta$-Glucosidase activity $(\mu \mathrm{mol} / \mathrm{h}$ per $\mathrm{g}) \|$ & $12 \cdot 43$ & $11 \cdot 30$ & 16 & $19 \cdot 04$ & 13.45 & 16 & 14.05 & 8.80 & 9 & $20 \cdot 37$ & $13 \cdot 27$ & 9 \\
\hline Phenol $(\mathrm{mmol} / \mathrm{kg})$ ๆ & 0.20 & 0.18 & 13 & $0.96^{\star \star}$ & 0.93 & 13 & 0.48 & 0.34 & 8 & 0.79 & 0.95 & 8 \\
\hline$p$-Cresol $(\mathrm{mmol} / \mathrm{kg})$ q & $0 \cdot 10$ & 0.11 & 13 & 0.22 & 0.19 & 13 & 0.20 & 0.12 & 8 & $0 \cdot 10$ & 0.09 & 8 \\
\hline
\end{tabular}

Mean values were significantly different from those of pre-weaned breast-fed infants: ${ }^{\star} P<0.05,{ }^{\star \star} P<0.01,{ }^{\star \star \star} P<0.001$.

Mean value was significantly different from that of pre-weaned formula-fed infants: $\dagger P<0.05$.

$\ddagger$ For details of subjects and procedures, see p. 510 .

$\S$ Mean age (weeks): breast-fed pre-weaned 6, weaned 26; formula-fed pre-weaned 6, weaned 23.

|| Mean age (weeks): breast-fed pre-weaned 5, weaned 33; formula-fed pre-weaned 7, weaned 27.

I Mean age (weeks): breast-fed pre-weaned 7, weaned 31; formula-fed pre-weaned 6, weaned 27.

\& Lee, 1982; Heavey \& Rowland, 1999) are reflected in changes in microbial activity in the gut. Overall, the concentrations of phenol, $p$-cresol, $\mathrm{NH}_{3}$, and $\mathrm{NH}_{3}$ production, as well as activities of $\beta$-glucuronidase and $\beta$-glucosidase in infant faeces, were found to be substantially lower in most infants than in adults.

The results from the present study also confirm that there were differences in faecal $\mathrm{NH}_{3}$ concentrations between infants exclusively fed breast or formula milk, although this effect became less evident as the infants got older and were introduced to a more varied diet. This is comparable with a study conducted by Guérin-Danan et al. (1997), who reported an average $\mathrm{NH}_{3}$ concentration of $6.7 \mu \mathrm{mol} / \mathrm{g}$ faecal sample from infants $(n$ 35) aged 10-18 months. However, there was wide variation in faecal $\mathrm{NH}_{3}$ production and no differences were observed between breast- and formula-fed infants. $\mathrm{NH}_{3}$ has toxic effects on gut mucosal cells, which include a reduction in the lifespan of these cells. Mammalian cells in culture can only tolerate modest concentrations of $\mathrm{NH}_{3}$ due to disruptions in intracellular pH (Visek, 1978). However, it is difficult to extrapolate the results from such in vitro studies to the concentrations found in the infant and adult faeces.

Although the level of phenol in infants' faeces was substantially lower than those found in those of adults (Smith \& MacFarlane, 1996; Table 1), this was not observed for $p$-cresol. There were also no apparent differences between breast- and formula-fed infants for either phenol or $p$-cresol. A likely explanation for this is that the formula feeds currently available, including the products used in the present study, contain similar amounts of tyrosine (the substrate from which gut bacteria generate phenol and $p$-cresol) to levels found in breast milk. Phenols are usually detoxified by either sulfate or glucuronide conjugation in the colonic mucosa and then excreted in the urine or remain unabsorbed and excreted in the faeces (Ramakrishna et al. 1989).

Faecal bacterial enzyme activity remained low in most infants compared with adults (Table 1), except for some babies with extremely high levels of both enzymes. This may reflect the specific bacterial flora in the infants, since different bacterial types express different levels of $\beta$-glucuronidase and $\beta$-glucosidase activities (Saito et al. 1992). Guérin-Danan et al. (1997) reported levels less than those found in infants aged 10-18 months compared with levels in adults. Again, there were some individual infants with very high levels of both enzymes.

With regards to $\beta$-glucuronidase, our present results show that exclusively formula-fed infants had significantly higher enzyme activities than exclusively breast-fed babies. After weaning, the formula-fed infants exhibited significantly greater $\beta$-glucuronidase activity compared with their breast-fed counterparts, although this was not significant. Our present results are consistent with those of Grönlund et al. (1999), who reported higher enzyme activity in formula-fed infants (before and after weaning), but not with the study of Mykkänen et al. (1997) who found no differences between the groups. The inconsistency between studies may be linked to the different types of formula feed used (Heavey \& Rowland, 1999).

$\beta$-Glucosidase activity was slightly higher (although not significantly so) in completely breast-fed compared with completely formula-fed infants, possibly due to the presence of bifidobacteria and lactobacilli, which are frequently present at greater concentrations in breast-fed babies. Both bifidobacteria and lactobacilli possess high levels of $\beta$-glucosidase (Saito et al. 1992; Rowland \& Tanaka, 1993). This difference was less evident after weaning and activity of $\beta$-glucosidase increased in both groups after weaning.

It has long been recognised that breast milk is the ideal food for the developing infant. The results from the present study demonstrate significant differences in faecal $\mathrm{NH}_{3}$ and $\beta$-glucuronidase concentrations between pre-weaned breast- and formula-fed infants. However, it would appear that changes occur in most faecal biochemical characteristics for all infants as they get older. This may be a response for the introduction of a weaning diet combined with the maturation of the gut and gut enzymes. To what extent early feeding patterns influence adult microbiota activities remains to be established. 


\section{Acknowledgements}

This study has been carried out with financial support from the European Commission of Agriculture and Fisheries, Fair specific RTD programme CT973181, 'New methodologies for studying diet and gut maturation in early life'. It does not necessarily reflect the Commission's views and in no way anticipates future policy in this area.

\section{References}

Bakke OM (1969) Studies on the degradation of tyrosine by rat caecal contents. Scandinavian Journal of Gastroenterology 4 , 603-608.

Balmer SE \& Wharton BA (1989) Diet and fecal flora in the newborn: breast milk and infant formula. Archives of Disease in Childhood 64, 1672-1677.

Benno Y, Sawada K \& Mitsuoka T (1984) The intestinal microflora of infants: composition of faecal flora in breast fed and bottle fed infants. Microbiology and Immunology 28, 975-986.

Bettelheim KA \& Lennox-King SMJ (1976) The acquisition of Escherichia coli by newborn babies. Infection 4, 174-179.

Escherich T (1885) Die Darmbaklerien des Neugeborenen und Säuglings (The Colonic Microflora of New-born Babies and Infants). Fortschritte der Medicin 3, 515-522, 547-554.

Gangolli SD \& Rowland IR (1999) Role of gastrointestinal flora in the metabolic and toxicological activities of xenobiotics. In General and Applied Toxicology, pp. 561-576 [TC Marrs, $\mathrm{T}$ Syverson and B Ballantyne, editors]. London: Macmillan Publisher Ltd.

Gareau FE, Mackel DG, Boring JR, Payne FJ \& Hammett FL (1959) The acquisition of fecal flora by infants from their mothers during birth. Journal of Pediatrics 54, 313-318.

Goldin BR (1986) In situ bacterial metabolism and colon mutagens. Annual Reviews of Microbiology 40, 367-393.

Grönlund M, Salminen S, Mykkänen H, Kero P \& Lehtonen O (1999) Development of intestinal bacterial enzymes in infants - relationship to mode of delivery and type of feeding. Acta Pathologica, Microbiologica et Immunologica Scandinavica 107, 655-660.

Guérin-Danan C, Andrieux C, Popot F, Charpilienne A, Vaissade P, Gaudichon C, Pedone C, Bouley C \& Szylit O (1997) Pattern of metabolism and composition of the fecal microflora in infants 10 to 18 months old from day care centers. Journal of Paediatric Gastroenterology and Nutrition 25, 281-289.

Heavey PM \& Rowland IR (1999) The gut microflora of the developing infant: microbiology and metabolism. Microbial Ecology in Health and Disease 11, 75-83.

Lifschifz CH, Wolin MJ \& Reed J (1990) Characterization of carbohydrate fermentation in feces of formula fed and breast fed infants. Pediatric Research 27, 165-169.

MacFarlane GT, Cummings JH \& Allison C (1986) Protein degradation by human intestinal bacteria. Journal of General Microbiology 132, 1647-1656.

Mata LJ \& Urrutia JJ (1971) Intestinal colonisation of breast fed children in a rural area of low socioeconomic area. Annals of the New York Academy of Science 176, 93-109.

Midtvedt AC \& Midtvedt T (1992) Production of short chain fatty acids by the intestinal microflora during the first two years of human life. Journal of Pediatric Gastroenterology and Nutrition 15, 161-168.

Midtvedt AC \& Midtvedt T (1993) Conversion of cholesterol to coprostanol by the intestinal microflora during the first two years of life. Journal of Pediatric Gastroenterology and Nutrition 17, 161-168. 
Mykkänen H, Tikka J, Pitkänen T \& Hänninen O (1997) Fecal bacterial enzyme activities in infants increase with age and adoption of adult-type diet. Journal of Paediatric Gastroenterology and Nutrition 25, 312-316.

Norin KE, Gustafsson BE, Lindblad BS \& Midtvedt T (1985) The establishment of some microflora associated biochemical characteristics in feces from children during the first 2 years of life. Acta Paediatrica Scandinavica 74, 207-212.

Parrett AM \& Edwards CA (1997) In vitro fermentation of carbohydrate by breast fed and formula fed infants. Archives of Disease in Childhood 76, 249-253.

Ramakrishna BS, Gee D, Weiss A, Pannall P, Roberts-Thomson IC \& Roediger WEW (1989) Estimation of phenolic conjugation by colonic mucosa. Journal of Clinical Pathology 42, $620-623$.

Rowland IR (1992) Metabolic interaction in the gut. In Probiotics: The Scientific Basis, pp. 29-53 [R Fuller, editor]. London: Chapman and Hall.

Rowland IR (1995) Toxicology of the colon: role of the intestinal microflora. In Human Colonic Bacteria: Role in Nutrition, Physiology and Pathology, pp. 154-174 [GR Gibson and GT MacFarlane, editors]. Boca Raton, FL: CRC Press.

Rowland IR \& Tanaka R (1993) The effects of transgalactosylated oligosaccharides on gut flora metabolism in rats associated with a human fecal microflora. Journal of Applied Bacteriology 74, 667-674.
Saito Y, Takano T \& Rowland IR (1992) Effects of soybean oligosaccharides on the human gut microflora in in vitro culture. Microbial Ecology in Health and Disease 5, 105-110.

Sarkany I \& Gaylarde CC (1968) Bacterial colonisation of the skin of the newborn. Journal of Pathology and Bacteriology 95, $115-122$.

Smith EA \& MacFarlane GT (1996) Enumeration of human colonic bacteria producing phenolic and indolic compounds: effects of $\mathrm{pH}$, carbohydrate availability and retention time on dissimilatory aromatic amino acid metabolism. Journal of Applied Bacteriology 81, 288-302.

Solorzano L (1969) Determination of ammonia in natural waters by the phenol-hypochlorite method. Limnology and Oceanography 14, 799-801.

Stark PL \& Lee A (1982) The microbial ecology of the large bowel of breast fed and formula fed infants during the first year of life. Journal of Medical Microbiology 15, 189-203.

Visek WJ (1978) Diet and cell growth modulation by ammonia. American Journal of Clinical Nutrition 31, s216-s220.

Wise A, Mallet AK \& Rowland IR (1982) Dietary fibre, bacterial metabolism and toxicity of nitrate in rat. Xenobiotica $\mathbf{1 2}$, $111-118$.

Yoshioka H, Iseki H \& Fujita K (1983) Development and differences of intestinal flora in the neonatal period in breast fed and bottle fed infants. Pediatrics 72, 317-321. 